\title{
Medical conditions underlying recurrence of retinal vein occlusion
}

\author{
P M DODSON, ${ }^{2}$ A J KUBICKI, ${ }^{2} \mathrm{~K}$ G TAYLOR, ${ }^{2}$ AND E E KRITZINGER'
}

From the 'Department of Medical Ophthalmology, Birmingham and Midland Eye Hospital, and the 'Clinical Investigation Unit, Dudley Road Hospital, Birmingham

SUMMARY Seventeen patients with recurrent retinal vein occlusion were investigated for underlying medical conditions and compared with 61 patients with single retinal vein occlusion (26 with central, 35 with branch vein occlusion). The two study groups were comparable for age, sex, and weight. Patients with recurrence had a significantly increased prevalence rate of hypertension $(88 \%$ versus $48 \%$ : $p<0.01)$, with a trend to increased hyperlipidaemia $(47 \%$ versus $33 \%)$ compared with patients with a single episode. A significantly raised mean systolic $(p<0 \cdot 05)$ but not diastolic blood pressure was found in patients with recurrence. Other cardiovascular risk factors in patients with recurrence were also found and included lower mean levels of high density lipoprotein $(\mathrm{HDL})$-cholesterol $(\mathrm{p}<0.02)$ and the $\mathrm{HDL}_{2}$ subfraction $(\mathrm{p}<0.001)$, and a significantly increased proportion of patients with regular alcohol intake $(\mathrm{p}<0 \cdot 01)$. We conclude that hypertension and hyperlipidaemia with an increase in other cardiovascular risk factors are commonly found in patients with recurrent retinal vein occlusion and may therefore be important aetiological factors. The possible benefits of treatment of these underlying conditions to prevent recurrence need to be assessed in well designed prospective studies.

Retinal vein occlusion is a common cause of visual loss in the United Kingdom. Its exact aetiology is unclear and therefore medical treatment is unsatisfactory. Management of it is aimed at identifying and treating the complications of retinal vein occlusion, and underlying medical conditions, for example, hypertension, hyperlipidaemia, diabetes mellitus, enhanced platelet activity, or hyperviscosity syndromes. ${ }^{1-5}$

However, reports have suggested that $15 \%$ of patients who have had a single retinal vein occlusion will go on to have another, commonly in the previously non-affected eye, with a consequent disastrous visual outcome. ${ }^{\circ}$ Patients with recurrent retinal vein occlusion have not been studied separately from those with single retinal vein occlusion, and so no data are available on why patients have a recurrence or which ones will do so.

We have therefore performed a study to identify the prevalence of medical conditions associated with recurrent retinal vein occlusion as compared with cases of single occlusion. Special emphasis has been

Correspondence to Dr P M Dodson, Clinical Investigation Unit, Dudley Road Hospital, Birmingham B18 7QH. paid to cardiovascular risk factors, including hypertension, hyperlipidaemia, and lipoprotein levels. These include the positively associated low density lipoprotein (LDL) and the negatively associated high density lipoprotein (HDL)-cholesterol and one of its subfractions $\mathrm{HDL}_{2}{ }^{\text {? }}$

\section{Patients and methods}

Sixty-one patients with single retinal vein occlusion (26 with central and 35 with branch retinal vein occlusion) and 17 patients with recurrent retinal vein occlusion were investigated serially with no prior selection at Birmingham and Midland Eye Hospital. The diagnosis of retinal vein occlusion, apart from suggestive clinical history and funduscopy, was confirmed by fluorescein angiography. Further clinical examination included a search for the presence of large vessel disease and a history of current drug therapy. After full clinical examination the following investigations were performed: full haematological profile, liver function tests, fasting lipid profile, and blood sugar.

Blood pressure was recorded after five minutes' rest in the sitting and supine position on an Accuson 
sphygmomanometer and the mean recorded. Diastolic pressure was recorded at the fifth Korotkoff phase.

Hypertension was defined as three consecutive blood pressure recordings of systolic greater than $160 \mathrm{mmHg}$ and diastolic greater than $95 \mathrm{mmHg}$ or when a patient was already established on antihypertensive drug therapy. Hyperlipidaemia was defined as a fasting serum cholesterol level greater than $7.1 \mathrm{mmol} / \mathrm{l}$ or serum triglyceride level greater than $2 \cdot 1 \mathrm{mmol} / \mathrm{l}$.

Serum cholesterol and triglyceride were measured by standard semiautomated techniques. HDLcholesterol was measured in the supernatant fraction following precipitation of very low density lipoprotein (VLDL) and LDL by heparin $(250$ units/50 $\mu \mathrm{l})$ and $1 \mathrm{M}$ manganese chloride $(50 \mu \mathrm{l})$ (coefficient of variation $2 \%){ }^{8}$ Further precipitation of the supernatant containing HDL with $100 \mu \mathrm{l}$ low molecular weight dextran sulphate $(14.3 \mathrm{~g} / \mathrm{l})$ as reported by Ferns et al. allowed measurement of the $\mathrm{HDL}_{3}$ subfraction. ${ }^{9}$ The $\mathrm{HDL}_{2}$ cholesterol level was calculated by subtraction of $\mathrm{HDL}_{3}$ level from the total

Table 1 Clinical details of patients studied with a single episode and recurrent vein occlusion

\begin{tabular}{|c|c|c|c|c|}
\hline Group & & $\begin{array}{l}\text { Form of } \\
\text { retinal vein } \\
\text { occlusion }\end{array}$ & $\begin{array}{l}\text { Mean age } \\
(y r)\end{array}$ & $\begin{array}{l}\text { Mean weight } \\
\text { (kg) }\end{array}$ \\
\hline $\begin{array}{l}\text { Single } \\
\text { retinal vein } \\
\text { occlusion } \\
(n=61)\end{array}$ & $\begin{array}{l}27 \mathrm{M} \\
34 \mathrm{~F}\end{array}$ & $\begin{array}{l}\text { BRVO (35) } \\
\text { CRVO (26) }\end{array}$ & $\begin{array}{r}61 \cdot 0 \\
\pm 13 \cdot 6\end{array}$ & $\begin{array}{r}70 \cdot 1 \\
\pm 12 \cdot 4\end{array}$ \\
\hline $\begin{array}{l}\text { Recurrent } \\
\text { retinal vein } \\
\text { occlusion } \\
(n=17)\end{array}$ & $\begin{array}{l}9 \mathrm{M} \\
8 \mathrm{~F}\end{array}$ & $\begin{array}{l}\text { Bilateral } \\
\text { BRVO (6) } \\
\text { Bilateral } \\
\text { CRVO (6) } \\
\text { Central and } \\
\text { BRVO (5) }\end{array}$ & $\begin{array}{r}65.94 \\
\pm 9.63\end{array}$ & $\begin{array}{r}72.42 \\
\pm 15.6\end{array}$ \\
\hline
\end{tabular}

BRVO and $\mathrm{CRVO}=$ Branch and central retinal vein occlusion respectively.
HDL cholesterol level. The results of $\mathrm{HDL}_{2}$ cholesterol measured by precipitation correlated well with results of preparative ultracentrifugation $(\mathrm{r}=+0.978, \quad \mathrm{p}<0.001)$." VLDL-cholesterol was measured after precipitation by sodium dodecyl sulphate $(100 \mathrm{~g} / \mathrm{l}$ in $0.15 \mathrm{M}$ sodium chloride; $75 \mu \mathrm{l})$. LDL-cholesterol was obtained by subtracting the sum of HDL and VLDL cholesterol from the total serum cholesterol.

Statistics were by unpaired $t$ test and the $\chi^{2}$ test with Yates's correction factor.

\section{Results}

The clinical details of the patients studied are shown in Table 1. The two groups were well matched for clinical details apart from the smaller number of patients in the recurrence group. This difference was expected owing to the low incidence of recurrence in those patients with single retinal vein occlusion.

Table 2 presents the prevalence of associated diseases in the two groups. The prevalence rates of associated medical conditions in the group of patients with single retinal vein occlusion used for comparison in this study were similar to those of larger series. ${ }^{23}$

There was a significantly increased prevalence rate of hypertension $(p<0.01)$ and a trend to an increase in the prevalence of hyperlipidaemia in those patients with recurrence compared with those with a single retinal venous event. The prevalence rates of hypercholesterolaemia and hypertriglyceridaemia showed an increase in the recurrent group, though this did not reach statistical significance. No significant differences were also observed (Table 3 ) between mean total serum cholesterol triglyceride and LDLcholesterol levels, but mean total HDL-cholesterol levels $(p<0.02)$ were significantly reduced in the recurrent group. This difference was due to a reduction in mean HDL 2 -cholesterol levels $(p<0.001)$ and not in $\mathrm{HDL}_{3}$ levels.

There was no difference between the groups with

Table 2 Prevalence rates of associated conditions in patients with single and recurrent retinal vein occlusion

\begin{tabular}{|c|c|c|c|c|}
\hline & Hypertension & Hyperlipidaemia & Hypercholesterolaemia & Hypertriglyceridaemia \\
\hline $\begin{array}{l}\text { Recurrent } \\
\text { retinal vein } \\
\text { occlusion } \\
(n=17)\end{array}$ & $88 \%(15)$ & $47 \%(8)$ & $35 \%(6)$ & $24 \%(4)$ \\
\hline Significance & $\mathrm{p}<0.01$ & NS & NS & NS \\
\hline $\begin{array}{l}\text { Single } \\
\text { retinal vein } \\
\text { occlusion } \\
(n=61)\end{array}$ & $48 \%(29)$ & $33 \%(20)$ & $28 \%(17)$ & $15 \%(9)$ \\
\hline
\end{tabular}

Statistics by the $\chi^{2}$ test. NS $=$ not significant. 
Table 3 Serum lipid and lipoprotein levels in patients with single and recurrent retinal vein occlusion

\begin{tabular}{|c|c|c|c|c|c|c|}
\hline & $\begin{array}{l}\text { Mean serum } \\
\text { cholesterol } \\
(M M)\end{array}$ & $\begin{array}{l}\text { Mean serum } \\
\text { triglyceride } \\
\text { (MM) }\end{array}$ & $\begin{array}{l}\text { Mean HDL } \\
\text { cholesterol } \\
(M M)\end{array}$ & $\begin{array}{l}\text { Mean } H D L_{2} \\
\text { cholesterol } \\
(M M)\end{array}$ & $\begin{array}{l}\text { Mean } H_{D L} L_{3} \\
\text { cholesterol } \\
(M M)\end{array}$ & $\begin{array}{l}\text { Mean LDL } \\
\text { cholesterol } \\
(M M)\end{array}$ \\
\hline \multirow{2}{*}{$\begin{array}{l}\text { Recurrent retinal } \\
\text { vein occlusion } \\
(n=17)\end{array}$} & $6 \cdot 36$ & 1.69 & $1 \cdot 24^{*}$ & $0 \cdot 30 \dagger$ & 0.93 & $3 \cdot 35$ \\
\hline & \pm 1.6 & $\pm 0 \cdot 74$ & $\pm 0 \cdot 3$ & $\pm 0 \cdot 11$ & $\pm 0 \cdot 31$ & $\pm 1 \cdot 12$ \\
\hline \multirow{2}{*}{$\begin{array}{l}\text { Single retinal } \\
\text { vein occlusion } \\
(n=61)\end{array}$} & $6 \cdot 3$ & 1.37 & 1.46 & 0.52 & 0.95 & $3 \cdot 17$ \\
\hline & \pm 1.4 & \pm 0.7 & \pm 0.3 & \pm 0.24 & \pm 0.25 & $\pm 1 \cdot 26$ \\
\hline
\end{tabular}

Values are mean $\pm S D .{ }^{*} p<0 \cdot 02$. $\dagger p<0 \cdot 001$.

$\mathrm{HDL}=$ high-density lipoprotein. $\mathrm{LDL}=$ low-density lipoprotein.

regard to the number of current cigarette smokers $(23.5$ versus $22.9 \%)$. In contrast, there was a significantly greater proportion of patients with a current regular alcohol intake ( $>7 \mathrm{~g}$ of alcohol/day) in the recurrent group than in the group with single retinal vein occlusion $(47 \%$ versus $13 \%$ : $p<0.01)$.

Further analysis with regard to blood pressure in the two groups (Table 4 ) revealed a significant increase in mean systolic blood pressure $(p<0.01)$ in the recurrent group, but the minor increase in diastolic blood pressure did not reach statistical significance. Table 5 analyses those patients with hypertension in the two groups. Of 15 patients with hypertension in the recurrent group seven were newly diagnosed and eight were on prior antihypertensive medication. However, to emphasise the possible importance of good blood pressure control only three patients on prior medication had normal blood pressure recordings.

\section{Discussion}

The striking result in this study is the finding of such a high prevalence rate of hypertension $(87 \%)$ in those patients with recurrent retinal vein occlusion. This finding, in conjunction with the raised mean levels of

Table 4 Mean blood pressure levels in the patients with single and recurrent retinal vein occlusion

\begin{tabular}{lcc}
\hline & $\begin{array}{l}\text { Mean } \\
\text { systolic blood } \\
\text { pressure }(\mathrm{mmHg})\end{array}$ & $\begin{array}{l}\text { Mean } \\
\text { diastolic blood } \\
\text { pressure }(\mathrm{mmHg})\end{array}$ \\
\hline $\begin{array}{l}\text { Recurrent } \\
\text { retinal vein } \\
\begin{array}{l}\text { occlusion } \\
(\mathrm{n}=17)\end{array}\end{array}$ & $175^{*}$ & $92 \cdot 1$ \\
$\begin{array}{l}\text { Singlc } \\
\text { retinal vein } \\
\text { occlusion } \\
(\mathrm{n}=61)\end{array}$ & $156 \cdot 6$ & $\pm 10 \cdot 0$ \\
\hline
\end{tabular}

Figures are mean $\pm \mathrm{SD} .{ }^{*} \mathrm{p}<0.05$ by unpaired $t$ test. blood pressure and the high number of patients with poor control of hypertension, lends further strong support to the view that hypertension is a major aetiological factor. This is supported by the recent observation of poorly controlled hypertension in five of eight patients who developed recurrence of retinal vein occlusion during a five- to 10-year follow-up period." These observations may also have implications with regard to the life expectancy of patients with retinal vein occlusion, as in a 10 -year prospective study of 226 patients the proportion with a vascular cause of death (cardiac or cerebral) was about double that expected from mortality statistics compiled for England and Wales. ${ }^{6}$ In view of the evidence that drug treatment of hypertension may reduce some hypertensive complications, particularly cerebrovascular episodes, ${ }^{12}$ it seems likely that good control of hypertension should reduce the mortality of patients with retinal vein occlusion from vascular causes and possibly recurrence of retinal vein occlusion. That retinal vein occlusion and cerebrovascular disease have a common aetiology in hypertension is therefore clear, but the situation differs in patients of different ethnic groups. For example, it has recently been noted that retinal vein occlusion, particularly the central form, is rarely seen

Table 5 Hypertension in the two groups of patients with retinal vein occlusion

\begin{tabular}{llll}
\hline $\begin{array}{l}\text { Hypertensive } \\
\text { group }\end{array}$ & \multicolumn{2}{l}{ Percentage and number of patients } \\
\cline { 2 - 4 } & $\begin{array}{l}\text { Newly } \\
\text { diagnosed }\end{array}$ & $\begin{array}{l}\text { On prior } \\
\text { antihypertensive } \\
\text { medication }\end{array}$ & $\begin{array}{l}\text { On prior } \\
\text { antihypertensive } \\
\text { medication but } \\
\text { still hypertensive }\end{array}$ \\
\hline $\begin{array}{l}\text { Recurrent retinal } \\
\text { vein occlusion } \\
(n=15)\end{array}$ & $47 \%(7)$ & $53 \%(8)$ & $63 \%(5)$ \\
$\begin{array}{l}\text { Single retinal } \\
\text { vein occlusion } \\
(n=29)\end{array}$ & $38 \%(11)$ & $62 \%(18)$ & $44 \%(8)$ \\
\hline
\end{tabular}


in blacks in two major ophthalmological centres serving large West Indian populations, ${ }^{13}$ but it is this group who have been reported to have the highest prevalence of hypertension associated with a high incidence of cerebrovascular disease ${ }^{14}$ Furthermore, hypertension is often severer in blacks than in the white community, in whom retinal vein occlusion is evidently more common. ${ }^{14}$

The exact mechanism of retinal venous damage by hypertension is unclear but possibilities include increased inflammatory activity, which has been demonstrated in hypertensive patients with retinal vein occlusion, ${ }^{1516}$ or indirect vascular damage to the retinal vein. This in turn may lead to vascular degeneration, with deposition of platelet aggregates.

Other cardiovascular risk factors for recurrence found in this study include an increased prevalence of hyperlipidaemia and reduced levels of HDLcholesterol and its subfraction $\mathrm{HDL}_{2}$. These findings might just express the presence of generalised vascular disease per se, but this is doubtful, as the prevalence of hyperlipidaemia appears to be significantly greater in patients with retinal vein occlusion than in control subjects with the same prevalence of overt macrovascular disease. ${ }^{3}$ Furthermore a significant postive relationship has been demonstrated between increasing serum cholesterol levels and the severity of retinal venous lesion on fluorescein angiograms. ${ }^{3}$ It would therefore appear that hyperlipidaemia may also be aetiological in single and recurrent retinal vein occlusion and that, in patients with a single retinal venous event, hyperlipidaemia and a low serum HDL-cholesterol might be more at risk of recurrence.

It is also of interest that there was a significant increase in the number of patients with a regular alcohol intake in the recurrence group. This may be a factor in the aetiology of the increased hyperlipidaemia and hypertension observed in this group. Smoking, another important cardiovascular risk factor, was not different in the two study groups.

Although no conclusions on the benefit of treating associated conditions to prevent recurrence can be made, this study does suggest the possibility that treatment of hypertension and hyperlipidaemia in these patients might be of value to prevent recurrence. This hypothesis has indeed recently been tested but in a non-controlled retrospective study of 22 hypertensive patients with retinal vein occlusion. The results were disappointing in that recurrence was not prevented, but this may well be due to the poor hypotensive control achieved by drug treatment and the failure to include treatment for hyperlipidaemia in this study. ${ }^{17}$
We conclude that hypertension and hyperlipidaemia, with an increase in other cardiovascular risk factors, are found in patients with recurrent retinal vein occlusion. These may therefore be important aetiological factors, but the exact mechanisms and the possible benefits of treatment need to be assessed in well designed prospective studies.

We are grateful to all the staff of the Medical Ophthalmology Clinic and Mrs B Singh for secretarial help.

\section{References}

1 Dodson PM, Galton DJ, Winder AF. Retinal vascular abnormalities in the hyperlipidacmias. Trans Ophthalmol Soc UK 1981; 101: 17-22.

2 Kohner EM, Cappin JM. Do medical conditions have an influence on central retinal vein occlusion. Proc R Soc Med 1974; 67: 1052-4.

3 Dodson PM, Galton DJ, Hamilton AM, Blach RK. Retinal vein occlusion and the prevalence of lipoprotein abnormalities. $\mathrm{Br} \mathrm{J}$ Ophthalmol 1982; 66: 161-4.

4 Dodson PM, Westwick J, Marks G, Kakkar VV, Galton DJ. Beta-thromboglobulin and platelet factor four levels in retinal vein occlusion. Br J Ophthalmol 1983; 67: 143-6.

5 Peduzzi M, De Rosa V, Fonda S, Coccheri S. Fibrinolytic response to venostasis as a prognostic factor for spontaneous recanalisation. Thromb Res 1981; 24: 105-18.

6 Rubinstein K, Jones EB. Retinal vein occlusion: long-term prospects, 10 years' follow-up of 143 patients. Br J Ophthalmol 1976; 60: 148-50.

7 Miller NE, Hammett F, Saltissi S, et al. Relation of angiographically defined coronary heart disease to plasma lipoprotein subfractions and apolipoproteins. $\mathrm{Br}$ Med $J$ 1981; 282: 1741-4.

8 Warnick GR, Albers JJ. A comprehensive evaluation of the heparin-manganese precipitation procedure for estimating high density lipoprotein cholesterol. J Lipid Res, 1978; 19: 65-76.

9 Ferns GA, Galton DJ, Landon J, Williams PJ. Measurement of high density lipoprotein subfraction $2\left(\mathrm{HDL}_{2}\right)$ by a simple precipitation method. Clin Sci 1981; 62: 16p-17p.

10 Pacy PJ, Dodson PM, Kubicki AJ, Fletcher RF, Taylor KG. Effect of a high fibre, high carbohydrate dietary regimen on serum lipids and lipoproteins in type II hypertensive diabetic patients. Diabetes Res 1984; 1: 159-63.

11 Kohner EM, Laatikainen L, Oughton J. The management of central retinal vein occlusion. Ophthalmology (Rochester) 1983; 90: 484-7.

12 Multiple Risk Factor Intervention Trial Research Group. Multiple risk factor intervention trial (MRFIT). JAMA 1982; 248: $1465-77$.

13 Dodson PM, Kritzinger EE. Underlying medical conditions in young patients and ethnic differences in retinal vein occlusion. Trans Ophthalmol Soc UK 1984; 104: 114-9.

14 Cruickshank JK, Becvers DG. Epidemiology of hypertension: blood pressure in blacks and whites. Clin Sci 1982; 62: 1-6.

15 Dodson PM, Shine B. Retinal vein occlusion: C-reactive protein and arterial hypertension. Acta Ophthalmol (Kbh) 1984; 62: 123-30.

16 Green WR, Chan CC, Hutchings GM, Terry JM. Central retinal vein occlusion: a prospective study of 29 cyes in 28 cases. Trans Am Ophthalmol Soc 1981; 79: 371-419.

17 Alvarez E, Trope GE. Retinal vein thrombosis despite treatment for hypertension. $J R$ Coll Physicians Lond 1984; 18: $142-3$. 